Chi, Tailan. (1994) Trading in Strategic Resources: Necessary Conditions, Transaction Cost Problems, and Choice of Exchange 1 Structure. Strategic Management Journal, 15 (4), 271-290. Publisher's official version:

<http://dx.doi.org/10.1002/smj.4250150403>. Open Access version: http://kuscholarworks.ku.edu/dspace/.

[This document contains the author's accepted manuscript. For the publisher's version, see the link in the header of this document.]

\title{
Trading in Strategic Resources: Necessary Conditions, Transaction Cost Problems, and Choice of Exchange Structure
}

\author{
By Tailan Chi \\ The University of Kansas
}

\section{Paper citation:}

Chi, Tailan. (1994) Trading in Strategic Resources: Necessary Conditions, Transaction Cost

Problems, and Choice of Exchange Structure. Strategic Management Journal, 15 (4), 271-290.

\begin{abstract}
:
The paper develops a theoretical framework for analyzing the exchange structure in the trading of imperfectly imitable and imperfectly mobile firm resources. It first explores the conditions for such resources to be gainfully traded between firms and then investigates the interconnections between barriers to imitation and impediments to trading. A major part of the paper is devoted to developing an integrative and yet parsimonious model for assessing the exchange structure between firms that are involved in the trading of strategic resources in the face of significant transaction cost problems. The model is applied in the last part of the paper to the analysis of the choice between acquisitions and collaborative ventures.
\end{abstract}


Chi, Tailan. (1994) Trading in Strategic Resources: Necessary Conditions, Transaction Cost Problems, and Choice of Exchange 2 Structure. Strategic Management Journal, 15 (4), 271-290. Publisher’s official version:

<http://dx.doi.org/10.1002/smj.4250150403>. Open Access version: http://kuscholarworks.ku.edu/dspace/.

TRADING IN STRATEGIC RESOURCES: NECESSARY CONDITIONS, TRANSACTION COST PROBLEMS, AND CHOICE OF EXCHANGE STRUCTURE

\author{
TAILAN CHI \\ Assistant Professor \\ School of Business Administration \\ University of Wisconsin-Milwaukee \\ P. O. Box 742 \\ Milwaukee, Wisconsin 53201-0742
}

(414)229-5429

Accepted for publication in Strategic Management Journal, 15 (4), 271-290, 1994.

Thanks are due to two anonymous referees for their constructive comments and suggestions, and also to Paul Nystrom and Masoud Yasai for their help and encouragement in the paper's revision process. All remaining errors, however, are my own responsibility. 
Chi, Tailan. (1994) Trading in Strategic Resources: Necessary Conditions, Transaction Cost Problems, and Choice of Exchange 3 Structure. Strategic Management Journal, 15 (4), 271-290. Publisher’s official version:

<http://dx.doi.org/10.1002/smj.4250150403>. Open Access version: http://kuscholarworks.ku.edu/dspace/.

\section{TRADING IN STRATEGIC RESOURCES: NECESSARY CONDITIONS, TRANSACTION COST PROBLEMS, AND CHOICE OF EXCHANGE STRUCTURE SUMMARY}

The paper develops a theoretical framework for analyzing the exchange structure in the trading of imperfectly imitable and imperfectly mobile firm resources. It first explores the conditions for such resources to be gainfully traded between firms and then investigates the interconnections between barriers to imitation and impediments to trading. A major part of the paper is devoted to developing an integrative and yet parsimonious model for assessing the exchange structure between firms that are involved in the trading of strategic resources in the face of significant transaction cost problems. The model is applied in the last part of the paper to the analysis of the choice between acquisitions and collaborative ventures. 
Chi, Tailan. (1994) Trading in Strategic Resources: Necessary Conditions, Transaction Cost Problems, and Choice of Exchange Structure. Strategic Management Journal, 15 (4), 271-290. Publisher’s official version:

<http://dx.doi.org/10.1002/smj.4250150403>. Open Access version: http://kuscholarworks.ku.edu/dspace/.

\section{INTRODUCTION}

The recent stream of research known as the resource-based view of the firm has underlined imperfectly imitable and imperfectly mobile firm resources as the roots of sustainable competitive advantage. Barney (1991: 101) defines firm resources as "all assets, capabilities, organizational processes, firm attributes, information, knowledge, etc. controlled by a firm that enable the firm to conceive of and implement strategies that improve its efficiency and effectiveness". A resource is imperfectly imitable if other firms face uncertainty in replicating the resource on their own (Lippman and Rumelt, 1982) and is imperfectly mobile if other firms encounter difficulty in acquiring the resource from its present employer (Peteraf, 1993). No firm can have resources with these two features, of course, unless the resources of different firms in an industry are heterogeneous (Rumelt, 1984; Wernerfelt, 1984). Furthermore, in order for an imperfectly imitable and imperfectly mobile resource to sustain any competitive advantage, it must be able to provide its employer with rents that are more than temporary ${ }^{1}$ and have no substitutes that are easily imitable or mobile (Barney, 1986b, 1991; Hill, 1991). In this paper, we will refer to resources of this nature as strategic resources. In the traditional strategy literature (Hitt and Ireland, 1985, 1986; Snow and Hrebiniak, 1980), such resources are commonly identified with a firm's distinctive competence in technology (secret know-how or superior R\&D capability), marketing (skills in bundling product attributes) and management (a valuable organization culture).

Although resource-based theorists generally agree that imperfect imitability and imperfect mobility are two prerequisites for a resource to sustain any competitive advantage, there has been continuing debate over their ramifications for a resource's tradability. Barney (1986a) maintains that there exist reasonably competitive (albeit imperfect) markets for strategic resources; Dierickx and Cool (1989), however, argue that truly unique and valuable resources such as reputation can not be readily acquired on a market and are thus not really tradable. As the 
Chi, Tailan. (1994) Trading in Strategic Resources: Necessary Conditions, Transaction Cost Problems, and Choice of Exchange Structure. Strategic Management Journal, 15 (4), 271-290. Publisher’s official version:

<http://dx.doi.org/10.1002/smj.4250150403>. Open Access version: http://kuscholarworks.ku.edu/dspace/.

debate has so far focused on the acquisition of a resource from its present employer, it has largely overlooked other means of trading such as replication of a resource under the guidance of its present employer. Consequently, a series of important questions concerning the trading of strategic resources have been left underexplored: Under what conditions, if any, can imperfectly imitable and imperfectly mobile resources be gainfully traded across firms? What are the main difficulties of trading in such resources? What mechanisms can be used to mitigate the various trading difficulties and how the exchange structure between the trading parties may be affected by the adoption of those mechanisms? It is the objective of this paper to raise and search for the answers to these questions.

After explicating a broader and hopefully more precise concept of trading in strategic resources, the paper spells out a set of conditions for the existence of gains from interfirm trade in such resources in the next section. It then moves on to investigate what types difficulties are likely to arise in the trading of imperfectly imitable and imperfectly mobile resources. Four primary transaction cost problems are identified in the analysis: adverse selection, moral hazard, cheating and holdup. A major part of the paper is subsequently devoted to examining the potential remedies for these transaction cost problems. Finally, the paper explores how the use of the various remedying mechanisms will affect the choice among different transaction modes in the trading of strategic resources, particularly, the choice between acquisition and collaborative venturing.

\section{CONDITIONS FOR STRATEGIC RESOURCES TO BE GAINFULLY TRADED ${ }^{2}$}

A strategic resource can be conceived as consisting of a number of different components. Some are physical assets, and others are skills held by the individuals working for the firm (Barney, 1991). The component assets and skills are organically linked with one another in the firm's technological and human systems by means of organization routines (Nelson and Winter, 1982). The various components of the resource may reside in one single unit or several different 
Chi, Tailan. (1994) Trading in Strategic Resources: Necessary Conditions, Transaction Cost Problems, and Choice of Exchange Structure. Strategic Management Journal, 15 (4), 271-290. Publisher’s official version:

<http://dx.doi.org/10.1002/smj.4250150403>. Open Access version: http://kuscholarworks.ku.edu/dspace/.

units of the firm (e.g., factories, departments, divisions or subsidiaries). As pointed out by Reed and DeFillippi (1990), physical assets alone can not provide a firm with any sustainable competitive advantage. So human skills and organization routines are essential components of any valuable resource and will be emphasized in the discussion that follows.

\section{Means of Trading in Strategic Resources}

Broadly speaking, trading in a strategic resource can occur by one of three means. One is the acquisition of the whole firm or the part of the firm in which the resource resides. The bidding of a strategic resource away from its present employer generally involves the acquisition of part of the employing firm. For example, to enhance its competence in developing computer operating systems, IBM could acquire Microsoft as a whole or only the part of Microsoft that specializes in operating systems for personal computers. ${ }^{3}$ Another is the purchase of the resource's service from the firm that possesses it. This is an indirect way of trading in strategic resources and has been in fact the adopted method of exchange between IBM and Microsoft. The third is the transfer of the skills and organization routines that make up the resource beyond the firm that presently employs it. This way of trading entails the replication of the resource under the guidance of its present employer. IBM could, for instance, create a new unit for developing PC operating systems and have the employees of that unit trained by Microsoft in a technology transfer arrangement. ${ }^{4}$

Note that the latter two ways of trading generally do not remove the resource from the possession of or eliminate its rent-generating potential for its present employer. Such exchanges are often carried out in collaborative ventures (e.g., cross licensing agreements or joint ventures). Whether any of the three means discussed above is a potentially viable way of trading hinges on, among other things, the nature of the resource in question in terms of its imitability and mobility. 
Chi, Tailan. (1994) Trading in Strategic Resources: Necessary Conditions, Transaction Cost Problems, and Choice of Exchange Structure. Strategic Management Journal, 15 (4), 271-290. Publisher’s official version:

<http://dx.doi.org/10.1002/smj.4250150403>. Open Access version: http://kuscholarworks.ku.edu/dspace/.

\section{Imitability, Mobility and Tradability}

There are considerable differences among the resource-based theorists in their conjectures regarding the imitability and mobility of strategic resources.

\section{Imitability}

Imperfect imitability can be conceptually ascribed to causal ambiguity—uncertainty about the causal connections between managerial actions and economic results (Lippman and Rumelt, 1982). The main conjectural difference with regard to this condition concerns a resource's potential to sustain competitive advantage when the firm that possesses the resource has better knowledge of the causal connections than potential imitators. Barney (1991) argues that, to be a source of sustained competitive advantage, both the firm that possesses the resources and the firms that seek to imitate them must be faced with the same level of causal ambiguity. Otherwise, competitors would be able to replicate the resources ceteris paribus by hiring away well-placed and knowledgeable managers of the firm. Reed and DeFillippi (1990), on the other hand, contend that competitive advantage can still be sustained under certain conditions even if the managers of the firm have better knowledge of the causal connections than its competitors. One such condition is the existence of barriers to the mobility of the firm's managers.

As suggested by Lippman and Rumelt (1982), a resource can not be perfectly mobile in the presence of uncertainty about its attributes among potential buyers. The linkages between imitability and mobility will be discussed in more detail in the next section. Suffice it here to point out that mobility barriers increase the cost and decrease the likelihood for competitors to replicate a firm's imperfectly imitable resources by engaging in such activities as hiring away its managers. It is therefore possible for a bundle of resources to possess a rent-generating capacity that is more than temporary even if the firm employing them has better knowledge than its competitors about how to replicate the resources. 
Chi, Tailan. (1994) Trading in Strategic Resources: Necessary Conditions, Transaction Cost Problems, and Choice of Exchange Structure. Strategic Management Journal, 15 (4), 271-290. Publisher’s official version:

<http://dx.doi.org/10.1002/smj.4250150403>. Open Access version: http://kuscholarworks.ku.edu/dspace/.

It is interesting to note that opportunities for mutually beneficial trading in strategic resources are not necessarily annulled by the condition that the firm possessing the resources experiences the same level of causal ambiguity as potential imitators. Suppose that a firm is known to be good at bundling product attributes made possible by new technology developed at other firms. Although its managers may not have better knowledge than its competitors about which of its skills and organization routines give it the advantage, exchanges between such a firm and specialized research firms to utilize their joint capabilities can still generate additional rents. The degree of causal ambiguity experienced by the firm possessing the resources, however, does have an impact on the choice among the different ways of trading, if trading ever occurs. The transfer of skills and organizational routines, for instance, will become less feasible as the firm itself faces a higher level of causal ambiguity.

\section{Mobility}

Imperfect mobility can be conceptually ascribed to specificity-the condition that a resource is specialized to firm-specific needs so that it has less value to other firms than to its present employer (Peteraf, 1993). Because they are firm-specific, markets for such resources are either highly imperfect or nonexistent. A resource is considered immobile when no one is expected to be able to bid it away from its present employer (Dierickx and Cool, 1989). The main conjectural difference with regard to the condition of mobility concerns the extent to which strategic resources can be traded across firms. Barney (1986a) maintains that there exist reasonably competitive (albeit imperfect) markets for strategic resources and that a firm should be able to gain competitive advantage via resource acquisition by seeking more accurate information about the future values of various resources. Dierickx and Cool (1989), on the other hand, assert that many strategic resources are not tradable on open markets and that a firm must develop these resources internally through steady investment in the relevant capabilities. 
Chi, Tailan. (1994) Trading in Strategic Resources: Necessary Conditions, Transaction Cost Problems, and Choice of Exchange Structure. Strategic Management Journal, 15 (4), 271-290. Publisher’s official version:

<http://dx.doi.org/10.1002/smj.4250150403>. Open Access version: http://kuscholarworks.ku.edu/dspace/.

Although progress toward the settlement of this difference seems to depend on further empirical work, we believe that more theoretical work is also needed to clarify what constitutes trading in strategic resources and gain a better understanding of the various impediments to trade. As suggested earlier, the bidding of a resource away from its present employer on the open market is but one method of exchange. The purchase of a resource's service and the transfer of skills and organization routines that make up the resource are perhaps more frequently used ways of trading in strategic resources. These latter two methods of exchange normally do not exclude the resource's present employer from the possession of it or the means to receive rents from it, so long as the number of firms with access to the resource remains small. When the exchange involves the supply of a resource's service (such as in many of the collaborative ventures between Corning Glass Works and its business partners), the firm providing the service may be able to prevent the service recipient from replicating the resource under conditions of causal ambiguity. Even when the firm helps another firm to replicate some of its rare skills and organization routines, it may still be able to restrict the recipient from using the resource to its detriment through legally enforceable property rights or self-enforceable contracts.

\section{Tradability}

Since our definition of trading in strategic resources includes more than the bidding of a resource away from its present employer, our concept of tradability is broader than the concept of mobility as defined by many resource-based theorists. Mobility concerns the potential that there exists another user to whom the resource's long-run value is higher than to its present employer (Peteraf, 1993). Our concept of tradability, however, concerns the potential that a possibly temporary use of the resource in conjunction with resources that are not put under the control of the firm can yield a higher return than its present best use within the firm. Such a use, moreover, does not have to exclude the resource from its present use within the firm. ${ }^{5}$ This concept is particularly useful in analyzing exchanges that do not involve the bidding of a 
Chi, Tailan. (1994) Trading in Strategic Resources: Necessary Conditions, Transaction Cost Problems, and Choice of Exchange Structure. Strategic Management Journal, 15 (4), 271-290. Publisher’s official version:

<http://dx.doi.org/10.1002/smj.4250150403>. Open Access version: http://kuscholarworks.ku.edu/dspace/.

resource away from its employer. Under this broader concept, firm-specific resources that are immobile across firms are not necessarily untradable.

Let's consider some examples of immobile resources cited by Dierickx and Cool (1989). Suppose an engineering company with a reputation for quality service wants to market its service in a previously closed economy but knows little about the country's infrastructure. If there exists a local engineering company that has a large pool of loyal customers in the country, an exchange between these two firms can potentially be mutually beneficial. In the process of the exchange, of course, both firms may run the risk of losing their competitive advantage to the other. But such risks are not always sufficiently large to offset their expected long-run gains from the exchange.

It should be emphasized, however, that potentially tradable resources will not necessarily be traded. A firm would not want to trade a resource in its possession when the expected gain from trading is below the expected cost. The preceding analysis has paved the ground for us to specify a set of conditions under which strategic resources can be gainfully traded.

\section{Necessary Conditions}

As long has been recognized in the literature on business strategy (Rumelt, 1974), the gain from trade in assets or resources between firms stems from the existence of complementarity or synergy between their assets or resources. Complementarity exists between two sets of resources when a joint use of them can potentially yield a higher total return than the sum of returns that can be earned if each set of resources are used independently of the other. ${ }^{6}$

In analyzing assets that are complementary in the commercialization of new technology, Teece (1986) distinguishes between specialized and generalized (or generic) assets depending on whether their value would be lower when they are used for another purpose. Here, we can adopt a similar distinction in analyzing resources that are complementary with the strategic resources of a firm. As explained in the introduction, strategic resources are heterogeneous across firms in 
Chi, Tailan. (1994) Trading in Strategic Resources: Necessary Conditions, Transaction Cost Problems, and Choice of Exchange Structure. Strategic Management Journal, 15 (4), 271-290. Publisher's official version:

<http://dx.doi.org/10.1002/smj.4250150403>. Open Access version: http://kuscholarworks.ku.edu/dspace/.

an industry, imperfectly imitable and imperfectly mobile, and have no substitutes that are easily imitable or mobile. Since they are by definition idiosyncratic (Barney, 1991), two sets of strategic resources that exhibit some complementarity necessarily have a degree of mutual dependence on each other and are thus cospecialized in the terminology of Teece. Although resources that are easily imitable or mobile can also help realize the rent-earning potential of strategic resources when there exists complementarity between them, such resources ex ante can be expected to receive normal returns only. For this reason, we choose to call this latter type of resources normal resources.

Based on the conceptual distinction between strategic and normal resources, we can identify two conditions under which gainful trading in strategic resources can occur. Each of them is a necessary condition while they are not jointly necessary. In the exposition of these conditions, we will assume that there are only two parties involved in the exchange. This assumption can be easily relaxed to deal with exchanges involving more than two parties.

Condition 1: Two firms that possess complementary strategic resources will have an incentive to trade their strategic resources when neither of them expects to be able to exploit the complementarity more profitably by trying to replicate the resources of the other on its own or acquire imperfect substitutes on the open market.

This condition is self-explanatory since strategic resources are imperfectly imitable and heterogeneous across firms.

Condition 2: When there exists complementarity between the strategic resources of one firm and the normal resources of another firm, the two firms will have an incentive to trade the strategic resources $a$ ) if the former does not expect to be able to exploit the complementarity more profitably by acquiring the normal resources on the open market and $b$ ) if the latter does not expect to be able to exploit the complementarity more 
Chi, Tailan. (1994) Trading in Strategic Resources: Necessary Conditions, Transaction Cost Problems, and Choice of Exchange Structure. Strategic Management Journal, 15 (4), 271-290. Publisher’s official version:

<http://dx.doi.org/10.1002/smj.4250150403>. Open Access version: http://kuscholarworks.ku.edu/dspace/.

profitably by trying to replicate the strategic resources of the former on its own or acquire imperfect substitutes on the open market.

Part $a$ ) of this condition needs a little explanation. Since normal resources (such as generic manufacturing, marketing or managerial skills) can be readily acquired on the open market, the firm that possesses the strategic resources would normally find internal diversification more profitable than trade (Teece, 1982). Government intervention such as restrictions on foreign investment can, of course, make internal diversification infeasible or unprofitable. In order for trade to be more profitable without the influence of such non-economic forces, however, a combination of two factors are necessary. The first is relatively tight appropriability regimes governing the firm's ability to capture rents generated by its strategic resources so that trading in the resources is not too costly (Teece, 1986). The second is that the management of the activities for the exploitation of the complementary can be more efficiently effected through the high powered incentive of the market than supervision under the hierarchy (Williamson, 1985). Both of these factors relate to transaction cost problems which we will examine next.

\section{BARRIERS TO IMITATION AND IMPEDIMENTS TO TRADING}

In this section, we will first discuss certain factors that have been recognized in the literature as sources of imperfect imitability and then move on to explore how these factors can give rise to transaction cost problems in the trading of strategic resources.

\section{Sources of Imperfect Imitability}

Reed and DeFillippi (1990) identified three characteristics that tend to give a resource high barriers to imitation: tacitness, complexity and specificity. These characteristics create imitation barriers by contributing to what Lippman and Rumelt (1982) call causal ambiguity because they cause uncertainty about what resource attributes are responsible for superior performance and how a firm can build resources with the right attributes. 
Chi, Tailan. (1994) Trading in Strategic Resources: Necessary Conditions, Transaction Cost Problems, and Choice of Exchange Structure. Strategic Management Journal, 15 (4), 271-290. Publisher’s official version:

<http://dx.doi.org/10.1002/smj.4250150403>. Open Access version: http://kuscholarworks.ku.edu/dspace/.

Tacitness characterizes skills and organization routines whose creation and replication heavily rely on learning by doing (Penrose, 1959; Polanyi, 1967). When a firm's distinctive competence involves a substantial amount of tacit knowledge, the sources of the firm's superior performance will appear ambiguous to its competitors, thus making imitation difficult (Nelson and Winter, 1982).

Complexity arises from the existence of many different and interrelated skills and organization routines within a firm (Nelson and Winter, 1982). The many different components may reside in different links of the firm's value chain (Porter, 1980) and have to be joined together in a complex social system. Complex human and technological systems can aggravate causal ambiguity in two ways. First, it is difficult to identify which attributes of such a system are responsible for the firm's success or failure (Barney, 1985). Second, even if the performance implications of the system's essential attributes can be identified, the means to engineer such a system are certainly beyond the knowledge of any firm at the present time (Barney, 1991; Dierickx and Cool, 1989).

Specificity refers to the condition that a resource is specialized to the needs of specific transactions, either within the firm or between the firm and its suppliers or customers (Williamson, 1985). Within the firm, specificity and complexity are closely intertwined. When a firm's strategic resources consist of many different skills and organization routines, the skills and organization routines are normally adapted to one another to increase efficiency, and the resources consequently become cospecialized (Teece, 1986). Not only the process of cospecialization often involves a lot of learning by doing, the attainment of cospecialization also adds complexity to the firm's technological and human systems. The outcome is therefore heightened barriers to imitation.

Moreover, there can also be cospecialization between the resources of the firm and the resources of its suppliers or customers. Such cospecialization creates a sort of exclusive relationship between the firm and its business partners since it is supported by sunk investment in human 
Chi, Tailan. (1994) Trading in Strategic Resources: Necessary Conditions, Transaction Cost Problems, and Choice of Exchange Structure. Strategic Management Journal, 15 (4), 271-290. Publisher’s official version:

<http://dx.doi.org/10.1002/smj.4250150403>. Open Access version: http://kuscholarworks.ku.edu/dspace/.

and physical assets on both sides (Reed and DeFillippi, 1990). Again, because the investment required is not easily observable to outsiders, imitation is ostensibly difficult.

\section{Causal Ambiguity and Problem of Adverse Selection}

As mentioned earlier, causal ambiguity often involves information asymmetry between the employing firm and potential acquirers about the content and quality of the resource in question (Reed and DeFillippi, 1990). Such information asymmetry, as shown by Akerloff (1970), will give rise to the problem of adverse selection, possibly causing market exchanges in the resource to break down. As an example, suppose that a chemical compound can be produced using several different processes that are developed by different firms and vary considerably in terms of production costs. In the presence of causal ambiguity, a potential acquirer of the process technology will tend to have less accurate information about its cost effectiveness than its present employer. Knowing this asymmetric distribution of information, the potential acquirer will be cautious in negotiation and motivated to bid a price that is near the lower bound of its possible values. If the bid happens to be higher than the potential seller's assessment of its long-term economic value, the bid will in all likelihood be happily accepted. However, if the bid is lower than the seller's assessment (which is a more likely event), difficult bargaining is likely to follow and may well end without striking a deal. There is, therefore, an adverse selection of the potential acquirer's bid. Even if the present employer does not have better information, the presence of divergent beliefs and expectations can be just as onerous to the negotiation.

This problem affects not only the acquisition of the resource but also the purchase of the resource's service and the transfer of the skills that make up the resource (Arrow, 1962; Teece, 1982). Although a firm may be known to be successful in a certain product or service market, other firms are still likely to have inferior information on the extent to which each particular set of the firm's skills have contributed to its success. 
Chi, Tailan. (1994) Trading in Strategic Resources: Necessary Conditions, Transaction Cost Problems, and Choice of Exchange Structure. Strategic Management Journal, 15 (4), 271-290. Publisher’s official version:

<http://dx.doi.org/10.1002/smj.4250150403>. Open Access version: http://kuscholarworks.ku.edu/dspace/.

\section{Tacitness and Problem of Moral Hazard}

Another source of exchange difficulties comes primarily from the tacitness of the skills and organization routines that make up a strategic resource. As pointed out by Polanyi (1967), tacit knowledge is difficult to articulate and can not be fully coded in technical manuals. Continue to use our earlier example of the chemical compound, the tacit part of the technology could include skills in controlling temperature and adjusting heating and cooling time in response to variations in input attributes from batch to batch. Consequently, if a potential acquirer chooses to have its own personnel trained by a firm that possesses such a technology or simply hire the firm to do the job, an extended period of service engagement of the firm will be required. The provision of such service, in the meantime, will inevitably engender a positive marginal cost on the part of the supplier in terms of engineering and managerial time (Teece, 1982). As the acquirer does not know exactly what sequence of actions should be taken in order to provide a good service, monitoring the actions of the supplier will be of little help for determining whether it is doing a good job. The acquirer may, nevertheless, be able to assess the supplier's performance indirectly if the outcome from the service is easily measurable and reflects the supplier's performance with reasonable accuracy. But if the outcome is also under the influence of the acquirer's own actions plus random external factors, the acquirer will face considerable difficulty measuring and evaluating the supplier's performance (Barzel, 1989).

Deficient performance measurement combined with a positive opportunity cost for the provision of the service will induce the supplier to shirk if it is engaged in performing the job through an arm's length deal. As shown by Chi (1991), the extent of shirking is likely to rise as performance measurement becomes more imperfect. Beyond a critical point, it will be inefficient for a potential acquirer to engage the firm for the service of its resource through an arm's length deal, and the market for the resource will break down. This problem is often referred to in the literature as moral hazard because it involves self-serving exercise of managerial discretion that one has promised to carry out in good faith and with diligence (Alchian and Woodward, 1988). ${ }^{7}$ 
Chi, Tailan. (1994) Trading in Strategic Resources: Necessary Conditions, Transaction Cost Problems, and Choice of Exchange Structure. Strategic Management Journal, 15 (4), 271-290. Publisher’s official version:

<http://dx.doi.org/10.1002/smj.4250150403>. Open Access version: http://kuscholarworks.ku.edu/dspace/.

In addition to creating impediments to trade in the service of a resource and its knowledge base, the moral hazard problem can also give rise to obstacles when a party tries to acquire the firm that commands the resource or the part of the firm in which the main components of the resource reside. This is primarily due to the difficulty that the acquirer may experience in motivating the acquired personnel in whom the desired skills and organization routines are embodied. First consider the case where the entire firm is acquired. Because of the idiosyncrasy of the skills and organization routines needed for efficient operation of the acquired firm, much of the original management may have to be left in place for at least some time (Grossman and Hart, 1986). Yet after the acquisition, the managers of the originally independent firm will have lost the discipline of the stock market and/or whatever direct ownership interest they may have in the firm. Under the moral hazard problem, this loss of what Williamson (1985) calls high-powered incentive can cause a significant degradation in their performance. ${ }^{8}$

In the case where only part of the firm is acquired, the employees of that part of the firm will be transferred to a new employer. The acquisition can impair the motivation of these individuals if they have made substantial investments in their human capital that are specific to the operation of their original employer. The reason is that the specificity of their skills to their original employer allows them to earn quasi-rents that they do not expect to get from their new employer (Williamson, 1985). ${ }^{9}$ As suggested by Lazear (1979), the receipt of quasi-rents from one's job makes one's own interests more compatible with those of one's employer since it raises the cost of losing the job (e.g., as a result of dismissal by or bankruptcy of the employer). The earning of quasi-rents as a motivating factor is presumably more important when the performance on the job is subject to high moral hazard. As mentioned earlier, human asset specificity is almost inevitable when a firm utilizes complex human and technological systems. 
Chi, Tailan. (1994) Trading in Strategic Resources: Necessary Conditions, Transaction Cost Problems, and Choice of Exchange Structure. Strategic Management Journal, 15 (4), 271-290. Publisher’s official version:

<http://dx.doi.org/10.1002/smj.4250150403>. Open Access version: http://kuscholarworks.ku.edu/dspace/.

\section{Complexity, Specificity, and Hazards of Cheating and Holdup}

We have suggested earlier that complexity and specificity are two interrelated characteristics of strategic resources. When a firm's resources consist of many different and interrelated skills and organization routines, cospecialization will inevitably arise among the various skills and routines, which in turn will add more complexity to the firm's network of resources. Such cospecialization makes the resources of the firm indivisible in the sense that the economic value of what remains of the firm will depreciate when a subset of its resources is removed (Hennart, 1988; Teece, 1982). As a subset of the firm's resources become more specialized to the rest, the firm will attach a higher value to those resources, and other firms will have to incur a higher cost in order to bid them away from the firm. In the resource-based work, cospecialization among the many different components of a firm's strategic resources is often considered the predominate barrier to the mobility of the resources (Peteraf, 1993).

Nevertheless, those firms whose resources are complementary with some subset of a particular firm's resources do not always have to detach those resources from the rest of that firm in order to gain access to them. Other options that they have include $a$ ) to acquire the entire firm, b) to purchase the service of the resources and $c$ ) to learn from the firm the skills and organization routines that make up the resources. If option $a$ ) is adopted, the complementary resources will be under the more or less unified command of the acquirer, and the main exchange difficulties will be the aforementioned adverse selection and moral hazard problems. Under options $b$ ) and $c$ ), however, the complementary resources will be shared between two autonomous entities. Such arrangements will inevitably create some resource interdependency between the two parties, which in turn can engender additional transaction cost problems even if the problems of adverse selection and moral hazard can be overcome. These additional transaction cost problems will be the focus of our attention in the rest of this section. 
Chi, Tailan. (1994) Trading in Strategic Resources: Necessary Conditions, Transaction Cost Problems, and Choice of Exchange Structure. Strategic Management Journal, 15 (4), 271-290. Publisher’s official version:

<http://dx.doi.org/10.1002/smj.4250150403>. Open Access version: http://kuscholarworks.ku.edu/dspace/.

\section{Resource Interdependency and Need for Coordination}

It is helpful to distinguish between two conditions of resource interdependency. One involves resources with the property of non-exclusion in use (Arrow, 1962). A resource that exhibits this property can be used by more than one party simultaneously while uncoordinated use of the resource by several parties will reduce the total amount of benefit that can be derived from it. A typical example is technological knowledge. Such knowledge can be used simultaneously by as many firms as can gain access to it; but the total rents that can be earned on the knowledge will not be maximized if the firms with access to it fail to behave like a perfect cartel (McGee, 1977). In fact, any resource that is embodied in human knowledge and skills would exhibit this property in some degree.

The second condition is cospecialization between two different sets of resources (Teece, 1986). When two sets of resources are cospecialized, the return that can be derived from the use of one set depends on how the other set are used simultaneously or sequentially. It is again economically desirable to establish some coordination between the parties who separately control the cospecialized resources. IBM's resources for making personal computers and Microsoft's resources for developing operating systems are examples of cospecialized resources. Cospecialization, of course, can also arise between normal resources such as facilities across contiguous stages of production. Evidently, trading in strategic resources can engender both of these conditions of resources interdependency and hence give rise to the need for coordination between the firms involved in the exchange.

\section{Cheating in Ex Ante Contractible Aspects of Coordination}

Based on Williamson's (1975) classification between ex ante and ex post contracting problems, Grossman and Hart (1986) suggested a distinction between ex ante contractible and ex ante noncontractible aspects of coordination. Conceivably, some aspects of coordination between two business partners are not dependent upon uncertain events in the future, so it is 
Chi, Tailan. (1994) Trading in Strategic Resources: Necessary Conditions, Transaction Cost Problems, and Choice of Exchange Structure. Strategic Management Journal, 15 (4), 271-290. Publisher’s official version:

<http://dx.doi.org/10.1002/smj.4250150403>. Open Access version: http://kuscholarworks.ku.edu/dspace/.

possible for them to clearly specify the obligations of each in these aspects at the outset of their relationship. Decisions on the usage of some technical know-how or the demarcation of sales territories, for example, can often be made early on in a business relationship. Yet, even though the two parties can reach a joint decision ex ante on how to coordinate along these aspects, the decision may still be nullified ex post if the party who is bound by the contractual obligation decides to cheat.

In contrast to shirking (i.e., moral hazard), which involves the evasion of a broadly specified obligation, cheating involves the breach of a precisely specified obligation that leaves little flexibility in the conduct of the contracting party. So it is generally appropriate to characterize the decision to shirk as a continuous choice and the decision to cheat as a dichotomous choice. In a technology transfer arrangement, for instance, the licensor's failure to provide sufficient training is shirking while the licensee's falsification of sales figures to reduce royalty payment is cheating. The distinction between shirking and cheating can become blurred, however, when the specification of an obligation leaves some flexibility in the conduct of the contracting party but the degree of such flexibility is rather limited. ${ }^{10}$

The temptation to cheat is due to a combination of two conditions. The first is the existence of gain from cheating under imperfect price constraints (Hennart, 1993). The other is the absence of effective punishment for cheating under imperfect behavioral constraints (Hennart, 1988; Teece, 1986). As suggested by Alchian and Woodward (1988), if an obligation can be precisely specified in a contract, its fulfillment will normally be relatively easy to ascertain. So imperfect monitoring is generally not as important as other deficiencies in enforcing the behavioral constraints. These enforcement imperfections include difficulty in producing satisfactory evidence for litigation or arbitration, insufficient means for retaliation, and inconsequentiality of such behavior to future business with any third parties (Hill, 1990). In short, so far as the ex ante contractible aspects of coordination are concerned, the hazard of cheating is the primary transaction cost problem hindering coordination. 
Chi, Tailan. (1994) Trading in Strategic Resources: Necessary Conditions, Transaction Cost Problems, and Choice of Exchange Structure. Strategic Management Journal, 15 (4), 271-290. Publisher’s official version:

<http://dx.doi.org/10.1002/smj.4250150403>. Open Access version: http://kuscholarworks.ku.edu/dspace/.

\section{Holdup in Ex Ante Noncontractible Aspects of Coordination}

Decisions on many aspects of coordination, nevertheless, can not be made on a once-andfor-all basis because of the need to make continual adaptations to unexpected changes in the external environment. Thus, coordination in these ex ante noncontractible aspects requires frequent joint decision making through negotiations between the two parties. The costs of bargaining associated with joint decision making have long been recognized by researchers in management and economics (Killing, 1983; Williamson, 1975). Recent advances in game theory, however, have uncovered a specific set of conditions under which bargaining costs arise. Rubinstein (1982) shows that bargaining can generally produce efficient results when the negotiators know exactly what the state of the world is and what each party's preferences are. So bargaining costs are essentially due to asymmetric distribution of information between the negotiators. The party with more information will have an incentive to take advantage of the situation, and the other party will correspondingly become defensive (Holmstrom, 1989). In addition, negotiators with divergent beliefs and expectations are also likely to expend excessive resources in bargaining (Sutton, 1986).

Milgrom and Roberts (1990) identified three sources of bargaining costs: mismatch of negotiation strategies, asymmetric information about contingencies, and uncertainty about each other's preferences. These asymmetries give rise to bargaining behavior that is intended to improve one's own position at the expense of the other but unavoidably erodes the total size of the pie to be divided. Examples of such behavior may include threats, delays, obfuscations and misrepresentations. In this paper, we choose to use the term holdup to refer to any opportunistic behavior that may abate the efficiency of joint decision making. ${ }^{11}$ The dispute between IBM and Microsoft over the promotion of OS/2 in the last few years might be considered a holdup problem. Conceivably, firms involved in the trading of some rare and idiosyncratic resources are not likely to have complete information about the other's negotiation strategies, contingencies or 
Chi, Tailan. (1994) Trading in Strategic Resources: Necessary Conditions, Transaction Cost Problems, and Choice of Exchange Structure. Strategic Management Journal, 15 (4), 271-290. Publisher’s official version:

<http://dx.doi.org/10.1002/smj.4250150403>. Open Access version: http://kuscholarworks.ku.edu/dspace/.

preferences. Hence, their coordination in the use of the strategic resources can be severely hampered by the hazard of holdup.

\section{Summary}

We have argued that strategic resources characterized by tacitness, complexity or specificity not only pose high barriers to imitation but also tend to subject trading in the resources to high transaction costs. In the course of discussion, we have identified four primary transaction cost problems: adverse selection, moral hazard (shirking), cheating and holdup. Each of these problems has its roots in one or more of the factors that have been recognized as sources of imperfect imitability. On a broader level, however, the relationship between imitation barriers and transaction costs can be seen as correlational. In other words, resources that have high barriers to imitation are also likely to engender high transaction costs in trading. In the next section, we will move on to analyze some principal mechanisms for remedying these transaction problems and their implications for the exchange structure in the trading of strategic resources. An overview of the four primary transaction cost problems and two principal remedying mechanisms are shown in Figure 1.

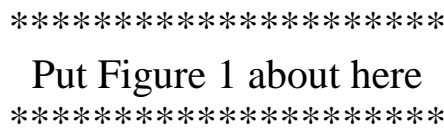

\section{STRUCTURAL REMEDIES FOR TRANSACTION COST PROBLEMS}

Our analysis of the structural remedies can be assisted by a reflection on the affinities and distinctions between the transaction cost problems that we have just discussed in the preceding section. As indicated in our earlier discussion, both adverse selection and moral hazard arise from some information asymmetry between the potential supplier and the potential acquirer of a strategic resource. Adverse selection is due to the difficulty that a prospective acquirer faces in assessing the skills and capabilities of the supplier. Moral hazard, meanwhile, is due to the difficulty that the acquirer faces in ascertaining the supplier's effort in providing its skills and 
Chi, Tailan. (1994) Trading in Strategic Resources: Necessary Conditions, Transaction Cost Problems, and Choice of Exchange Structure. Strategic Management Journal, 15 (4), 271-290. Publisher’s official version:

<http://dx.doi.org/10.1002/smj.4250150403>. Open Access version: http://kuscholarworks.ku.edu/dspace/.

capabilities. Since these two problems both result from measurement difficulties and both affect the value to be created in an exchange, they are susceptible to some similar remedies.

In contrast to adverse selection and moral hazard, which primarily concern the value creation aspect of trading in strategic resources, cheating and holdup primarily affect the appropriation of the value that the relevant resources can potentially generate. As pointed out earlier, trading in strategic resources tend to create two conditions of resource interdependency: access by more than one firm to resources that exhibit the property of non-exclusion in use and split control over cospecialized resources between two autonomous firms. These two conditions entail close coordination between the transacting parties in the use of the resources and at the same time give rise to opportunities for them to gain at the expense of the other through cheating or holdup. Since cheating and holdup both result from resource interdependency and both can cause the needed coordination to fail, they are also subject to some common remedies.

\section{Measurement Problems and Apportionment of Residual Claimancy}

At the risk of oversimplifying, we may classify the potential remedies for the problems of adverse selection and moral hazard (see Kreps, 1990 for a review) into two distinct types. The first type of remedies rely on the substitution of reputation for costly measurement. This type of remedies can potentially revive market trading in goods and services that engender severe measurement difficulty, but their applicability is subject to conditions that strategic resources often do not meet. Their applications and limitations are briefly discussed in the Appendix. Our analysis in the paper will focus on the second type of remedies - the apportionment of residual claimancy between the parties involved in the exchange.

Residual claimancy refers to the extent to which an input contributor bears the variation of the outcome from the production process it participates in (Barzel, 1989). By linking an input contributor's payoff with the outcome of the production process, this type of remedies can be used to alleviate both the problems of adverse selection and moral hazard. In the face of the ad- 
Chi, Tailan. (1994) Trading in Strategic Resources: Necessary Conditions, Transaction Cost Problems, and Choice of Exchange Structure. Strategic Management Journal, 15 (4), 271-290. Publisher's official version:

<http://dx.doi.org/10.1002/smj.4250150403>. Open Access version: http://kuscholarworks.ku.edu/dspace/.

verse selection problem, a resource supplier's willingness to have its payoff linked to the outcome of the production process gives its business partner a signal as to the quality of its resources (Hallagan, 1978). The reason is that a high-quality supplier is likely to have a more optimistic assessment of the outcome and is thus on expectation more willing to accept such a linkage than a low-quality supplier. In the meantime, such a linkage also gives the supplier an incentive to contribute its resources to the production process, thus also alleviating the problem of moral hazard (Eswaran and Kotwal, 1985).

The apportionment of residual claimancy can take many different forms since the outcome of a production process is generally reflected in a multiple of measures, such as profit, sales, output, productivity and quality. The rule is, of course, to make the input contributor's payoff contingent upon a variable (or variables) that most closely measures its contribution (Holmstrom, 1979). In the transfer of well-coded technology, for instance, the technology supplier's payoff is often partly contingent upon the start of smooth production runs and satisfaction of some quality standards for the output (Contractor, 1981). Similarly in the marketing of well-defined products, the distributor's payoff is often partly based on the volume of sales. In the trading of complex strategic resources, however, such "warranty" and "deduction" type of arrangements are likely to be inadequate. ${ }^{12}$

As suggested by Hennart (1989), the effect of a rent-earning resource is often quite complex and its best measure is generally the profit from the operation. ${ }^{13}$ Frequently, both of the parties involved in the trading of strategic resources are expected to have substantial influences on the production process that can only be meaningfully measured by the profit from their exchange. In such a case, an efficient arrangement must involve profit sharing between the two parties. Given that a rise in one party's share means a fall in the other party's share, the relative share between them will have to be balanced in order to take into account the measurement problems engendered by both (Barzel, 1987). 
Chi, Tailan. (1994) Trading in Strategic Resources: Necessary Conditions, Transaction Cost Problems, and Choice of Exchange Structure. Strategic Management Journal, 15 (4), 271-290. Publisher’s official version:

<http://dx.doi.org/10.1002/smj.4250150403>. Open Access version: http://kuscholarworks.ku.edu/dspace/.

Hence, the apportionment of residual claimancy seems to be the principal mechanism for remedying the problems of adverse selection and moral hazard in the trading of strategic re-

sources. ${ }^{14}$ It helps the parties involved in the exchange to devise a proper compensation structure for the alleviation of the measurement problems. The actual compensation structure set up between two business partners can be very complex. But conceptually, it can range from one party bearing all residual claimancy (i.e., all the variation in the outcome) to the other bearing all residual claimancy. Apart from the two extremes, of course, the residuals are shared between the two parties and can be adjusted virtually along a continuum.

\section{Coordination Failures and Assignment of Residual Control}

The potential remedies for the hazards of cheating and holdup (see Williamson, 1985 for a review) may also be classified into two types. The first type of remedies aim to avoid or limit the extent of resource interdependency, and the second type of remedies aim to build effective deterrence to cheating and holdup.

\section{Integration and Quasi-Integration}

A firm that finds another firm's resources complementary with its own will have an easy solution if the other firm's resources are either easily imitable or highly mobile. When the firm's own strategic resources exhibit the property of non-exclusion in use, the remedy called for is to maintain exclusive control over the resources by replicating or acquiring complementary resources (Casson, 1987). The growth of multinational enterprises (MNEs) is often attributed to the advantage of maintaining exclusive access to knowledge-based resources by internalizing the market for such resources (Caves, 1982; Rugman, 1981). When specialized assets are required in an adjacent stage of production that is not presently under the firm's control, the remedy called for is to integrate into the next stage to attain unified control over economically interdependent resources (Williamson, 1975). The integrated operation of aluminum companies has been attributed to the disadvantage of split control over contiguous stages of production (Stuckey, 
Chi, Tailan. (1994) Trading in Strategic Resources: Necessary Conditions, Transaction Cost Problems, and Choice of Exchange Structure. Strategic Management Journal, 15 (4), 271-290. Publisher’s official version:

<http://dx.doi.org/10.1002/smj.4250150403>. Open Access version: http://kuscholarworks.ku.edu/dspace/.

1983). Such horizontal or vertical integration, however, will be very costly and is thus likely to be a suboptimal solution when the resources that the firm wishes to acquire are subject to both high imitation barriers and high mobility barriers.

The benefit of exclusive or unified control, nevertheless, may still be partially attained through what Monteverde and Teece (1982) call quasi-integration-the extension of a firm's control rights to a subset rather than all of the resources employed in a vertically or horizontally related operation. When two firms choose to utilize their complementary capabilities in a joint project, they may be able to accomplish the undertaking without giving the other a chance to acquire their most prized trade secrets. In such a case, each party can retain exclusive control over their own resources without fully internalizing the market for the resources. But because interactions between the personnel of the two firms inevitably cause some information leakage, the effectiveness of such quasi-integration is necessarily limited. Similarly, a firm may also be able to gain control over certain crucial decisions in an adjacent stage of production without acquiring full control over the whole operation. This might be accomplished through staffing arrangements in the operation by putting one's own personnel in charge of the relevant managerial functions (e.g., manufacturing or marketing). Because there still exists significant resource interdependency between the two parties under such an arrangement, quasi-integration can only reduce but can not really completely eliminate the hazards of cheating and holdup.

\section{Deterrence Building}

When it is too costly to eliminate the conditions of resource interdependency, firms interested in the trading of strategic resources might try to build effective deterrence to cheating and holdup. The key to effective deterrence is to give each party sufficient means to retaliate against any opportunistic behavior of the other party (Williamson, 1985). Depending on the circumstances under which the exchange is taking place, such deterrence can take many different forms. 
Chi, Tailan. (1994) Trading in Strategic Resources: Necessary Conditions, Transaction Cost Problems, and Choice of Exchange Structure. Strategic Management Journal, 15 (4), 271-290. Publisher’s official version:

<http://dx.doi.org/10.1002/smj.4250150403>. Open Access version: http://kuscholarworks.ku.edu/dspace/.

If the two parties can not successfully replicate the other's resources in the exchange process, each will be able to penalize the other simply by withholding its cooperation or reducing its level of cooperation when it suspects the other of opportunism (Telser, 1980). As suggested by recent research in game theory, this type of punishment may be able to produce a strong enough deterrent even when monitoring is imperfect (Abreu, Pearce and Stacchetti, 1990). If the two parties are both able to replicate the other's resources in the exchange process, a breakdown in their cooperation can give rise to intense competition between them in the same output market. ${ }^{15}$ The prospect for such a joint loss due to a coordination failure may also be able to create a strong enough deterrent to opportunism (Hamel, Doz and Prahalad, 1989).

There will be insufficient deterrence, however, if the gain that one party can get from opportunism more than offsets the penalty the other can possibly impose. This can happen when one party can replicate the other's resources while successfully preventing the other from doing the same. Such a situation, nevertheless, may be remedied if the favorably positioned party provides the vulnerable party with a bond (Williamson, 1983). A joint venture in which each party sinks a significant amount of investment may be used as such a bond (Klein, Crawford and Alchian, 1978). It creates a mutual hostage taking situation that can deter not only cheating but also holdup since protracted bargaining would depreciate both parties' investment in the venture. The feasibility of such a remedy, however, is constrained by the size of the bond that the party is able to put up. It will be infeasible when the wealth of the potential culprit is much smaller than the anticipated gain from cheating. MNEs with proprietary technology often exhibit a strong aversion to having a local partner. Such aversion may be explained in some instances by the wealth constraints of the available local collaborators.

It should be noted that integration, quasi-integration and deterrence building all aim to achieve an economically efficient assignment of control rights. In the presence of the transaction cost problems of cheating and holdup, the control over the resources can not be economically effected through contractual stipulations alone. It has to rely on ownership and sometimes direct or 
Chi, Tailan. (1994) Trading in Strategic Resources: Necessary Conditions, Transaction Cost Problems, and Choice of Exchange Structure. Strategic Management Journal, 15 (4), 271-290. Publisher’s official version:

<http://dx.doi.org/10.1002/smj.4250150403>. Open Access version: http://kuscholarworks.ku.edu/dspace/.

even exclusive access to the relevant resources. To the extent that the acquisition and maintenance of such control involves property ownership, it is similar to what Grossman and Hart (1986) call residual rights of control. However, as has long been recognized by the property rights school (Cheung, 1969; Coase, 1960), an ownership title does not necessarily guarantee a party all the rights to a resource. A party's ownership rights to a resource can be vulnerable to infringements under the two conditions of resource interdependency outlined earlier.

Recognizing the possible incompleteness of ownership rights, we adopt the term residual control to emphasize the effective power that each party holds in making and implementing decisions concerning the relevant resource. ${ }^{16}$

In short, the assignment of residual control appears to be the principal mechanism for remedying the hazards of cheating and holdup in the trading of strategic resources. ${ }^{17}$ The use of such remedies is manifested in the control structure between the parties involved in the exchange. Like the dimension of residual claimancy, the control structure can also be conceptualized as ranging from one party holding all residual control to the other holding all residual control over the complementary resources. Apart from the two extremes, residual control must be divided or shared between the two parties in some manner. Unlike the dimension of residual claimancy, however, the control structure can only be adjusted in discrete increments.

As mentioned in the preceding section, the distinction between cheating and shirking can become blurred when the specification of an obligation leaves some flexibility in the conduct of the contracting party but the degree of such flexibility is rather limited. So for instances where these two types of opportunism are not easily distinguishable, both the apportionment of residual claimancy and the assignment of residual control may be effective remedies. In presence of other transaction cost problems, therefore, the constraint that this type of problems may impose on the choice of institutional structure is less likely to be binding. 
Chi, Tailan. (1994) Trading in Strategic Resources: Necessary Conditions, Transaction Cost Problems, and Choice of Exchange Structure. Strategic Management Journal, 15 (4), 271-290. Publisher's official version:

<http://dx.doi.org/10.1002/smj.4250150403>. Open Access version: http://kuscholarworks.ku.edu/dspace/.

\section{IMPLICATIONS FOR THE CHOICE OF TRANSACTION MODES}

We have in the preceding section identified two distinct dimensions of the exchange structure in the trading of strategic resources. The apportionment of residual claimancy influences the allocation of responsibility between the two parties for the variation in the outcome of their joint undertaking when their capabilities and/or efforts are difficult for the other to measure. A proper structural design along this dimension can minimize the friction in the value creation process brought about by adverse selection and moral hazard. The assignment of residual control influences the designation of authority between the parties over the synergistically related resources. A proper structural design along this dimension can minimize the potential value dissipation due to cheating and holdup. Although functionally distinct, these two dimensions of the exchange structure are not independent of each other because a change in one dimension often has implications for the other dimension.

In this section, we will first compare and contrast the different organization forms for the trading of strategic resources. Specifically, we will see how their features might be defined in terms of the apportionment of residual claimancy and the assignment of residual control between the transacting parties and how adjustable their features are along these to dimensions. A set of conditions for collaborative ventures to be superior to outright acquisitions are spelled out in the analysis. Then, we will explore some interactions between the two dimensions of the exchange structure and their implications for the choice of organization forms or transaction modes.

\section{Transaction Costs and Transaction Modes}

We have suggested earlier that trading in strategic resources can occur by one of three means: $a$ ) the acquisition of the entire firm or part of it that possesses the resources, $b$ ) the purchase of the service from the resources and $c$ ) the transfer of skills and organization routines that make up the resources. In the discussion of these different means of trading, our attention was focused on what type of activities are involved in the exchange: acquisition of organization units, 
Chi, Tailan. (1994) Trading in Strategic Resources: Necessary Conditions, Transaction Cost Problems, and Choice of Exchange Structure. Strategic Management Journal, 15 (4), 271-290. Publisher’s official version:

<http://dx.doi.org/10.1002/smj.4250150403>. Open Access version: http://kuscholarworks.ku.edu/dspace/.

provision of services, or teaching and learning activities. The focus of our attention in this section, however, will be shifted to how a given type of exchange activities might be organized in order to minimize the transaction cost problems present. The various organization forms for carrying out the exchange activities will be referred to as transaction modes and defined in terms of the apportionment of residual claimancy and the assignment of residual control between two parties.

\section{Acquisition}

The aim of acquisition is to effect the transfer of residual claimancy and residual control over the resources from their present employer to the acquirer. If the acquisition removes the original employer's access to any parts of the resources that exhibit the property of non-exclusion in use, the first condition of resource interdependency can be eliminated. This will be the case if the knowledge base for the resources resides only in the part of the firm that is transferred to the acquirer. Since the original employer supposedly also imparts control over the acquired resources to the acquirer, the second condition of resource interdependency can also be eliminated. So the hazards of cheating and holdup in the use of the complementary resources can basically be removed if the acquisition of the resources is complete.

As pointed out earlier, however, the acquirer may still face difficulty in assessing the value of the resources in the acquisition process and encounter a degradation of performance of the acquired personnel after the acquisition. Such measurement difficulties are manifested differently depending on whether the acquisition involves the entire firm or only part of it. When the acquisition target is an entire firm, the acquirer is likely to experience less of an adverse selection problem if the equity of the target firm is traded in an efficient stock market. In such a case, the main transaction cost problem hindering the acquisition would be moral hazard, and the problem would be more costly as the portion of the target firm that does not exhibit much complementarity with the resources of the acquirer is larger. ${ }^{18}$ When the acquisition target is 
Chi, Tailan. (1994) Trading in Strategic Resources: Necessary Conditions, Transaction Cost Problems, and Choice of Exchange Structure. Strategic Management Journal, 15 (4), 271-290. Publisher’s official version:

<http://dx.doi.org/10.1002/smj.4250150403>. Open Access version: http://kuscholarworks.ku.edu/dspace/.

only part of a firm, the adverse selection problem would be more severe because a portion of the firm does not have stand-alone market value, but the moral hazard problem might be less costly because any degradation of performance only affects part of the firm. The main impediment to the acquisition of part of a firm, though, is likely to stem from its specialization to the rest of the firm.

\section{Collaborative Venturing}

The alternative to acquisition is to purchase the service of the resources from their present employer or replicate the resources under its guidance. Such an exchange can be carried out through either an arm's length deal or a collaborative venture (CV). By an arm's length deal, we mean an exchange of some clearly defined goods or services for prespecified amounts of payment. For the purpose of this paper, we define a CV as any business venture between two firms each of which bears some residual claimancy in the venture and holds some residual control over the resources used by the venture. ${ }^{19}$ Since pure arm's length deals apply only in a world of tight appropriability regimes and zero transaction cost (Teece, 1986), our discussion will focus on CVs. Included under the rubric of CVs are not only equity and nonequity joint ventures (JVs) but also many other contractual arrangements involving technology licensing, management service, or long-term supply and marketing (Contractor and Lorange, 1987).

As the purchase of service and transfer of skills will both give rise to the need for performance measurement and the need for coordination, CVs are potentially subject to both measurement difficulties and coordination failures. First of all, the problems of adverse selection and moral hazard could create friction in the process of the exchange, attenuating the incremental gain from the joint use of complementary resources. In addition, the eventuation of the exchange could create strong temptation for cheating and holdup, causing the dissipation of the total rents

that the resources can potentially yield. Its susceptibility to the problems of cheating and holdup, however, does not have to make a CV less efficient than an outright acquisition. Because the ap- 
Chi, Tailan. (1994) Trading in Strategic Resources: Necessary Conditions, Transaction Cost Problems, and Choice of Exchange Structure. Strategic Management Journal, 15 (4), 271-290. Publisher’s official version:

<http://dx.doi.org/10.1002/smj.4250150403>. Open Access version: http://kuscholarworks.ku.edu/dspace/.

portionment of residual claimancy and the assignment of residual control can be adjusted within wide ranges in a $\mathrm{CV}$, it has the potential of providing a balanced bundle of remedies for the transaction cost problems engendered by the two parties.

The potential advantage of a CV over the complete acquisition of an entire firm is primarily due to the fact that both firms involved in the exchange can be apportioned some residual claimancy in a CV. As suggested by Barzel (1987), a balanced share of residual claimancy between two exchange parties can potentially minimize the measurement problems engendered by both. In addition, since the part of each firm that does not have any complementarity with any resources of the other is not involved in the $\mathrm{CV}$, any measurement difficulties will only affect the parts of the two firms that are coalesced in the CV. As shown by Pisano (1989), joint residual claimancy between two firms can also be effected when one firm acquires only part of the equity stock of another firm and leaves part of the equity stock in the hands of the acquired firm's original owner-managers. Since the original owner-managers of the acquired firm will still hold some residual control over the firm's resources under such an arrangement, it fits our definition of a CV.

The potential advantage of a CV over the acquisition of part of a firm is primarily due to the fact that neither firm relinquishes the resources that they supply to the venture, so that they can still use the resources together with other complementary and perhaps cospecialized resources within the firm (Kogut, 1988). This is the main reason that immobile resources might be tradable via a $\mathrm{CV}$.

It has been suggested that a necessary condition for CVs to be the optimal choice of transaction modes is the presence of high transaction costs in trading the inputs of both parties involved in a joint or contiguous production process (Hennart, 1988, 1991; Shan, 1987, 1990). Hennart (1988) has identified a set of conditions for the existence of equity JVs. Based on the analysis completed so far in our paper, we can adapt this set of conditions to a set of two jointly necessary conditions for a CV to be the optimal choice of transaction modes. 
Chi, Tailan. (1994) Trading in Strategic Resources: Necessary Conditions, Transaction Cost Problems, and Choice of Exchange Structure. Strategic Management Journal, 15 (4), 271-290. Publisher's official version:

<http://dx.doi.org/10.1002/smj.4250150403>. Open Access version: http://kuscholarworks.ku.edu/dspace/.

The first is that each of the two firms involved in a joint or contiguous production process has some resources that engender significant adverse selection or moral hazard in trading. If the resources that one of them possesses can be traded without these measurement difficulties, then it would be at least as good an arrangement for the other firm to acquire that firm in its entirety. The second condition is that the exploitation of the synergy between the two firms requires each of them to supply some resources that either are specialized to the rest of that firm or engender significant measurement difficulties. If one of them supplies no such resources, then it would be at least as good an arrangement for the other firm to acquire that part of the firm in which the desired resources reside.

This set of conditions are explained in a different way in Figure 2. The inferences drawn in the figure can be more precisely stated as follows. When the complementary resources of Firm $B$ are neither specialized to the rest of Firm $B$ nor subject to significant measurement difficulties, it will be at least as good as any other transaction mode if Firm $A$ acquires those complementary resources from Firm $B$. When no resources of Firm $B$ are subject to significant adverse selection or moral hazard, it will be at least as good as any other transaction mode if Firm $A$ acquires Firm $B$ as a whole, even if those resources of Firm $B$ that are complementary to those of Firm $A$ are specialized to the rest of Firm $B$. Otherwise, a CV may be a more advantageous transaction mode.

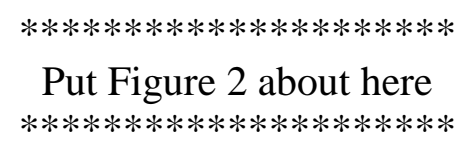

\section{Interactions Between the Two Structural Dimensions}

We have said earlier that the exchange structure between the trading parties can be adjusted, at least in discrete increments, along each of the two structural dimensions. Through an example below, we will illustrate that these two structural dimensions are not independent from 
Chi, Tailan. (1994) Trading in Strategic Resources: Necessary Conditions, Transaction Cost Problems, and Choice of Exchange Structure. Strategic Management Journal, 15 (4), 271-290. Publisher’s official version:

<http://dx.doi.org/10.1002/smj.4250150403>. Open Access version: http://kuscholarworks.ku.edu/dspace/.

each other because an adjustment along one dimension could have strong implications for the other dimension.

Consider the case where a firm supplies specialized parts to its JV with another firm. In an attempt to reduce the hazard of coordination failures, the two parties might put the supplier firm's personnel in charge of decisions related to the production in the JV including procurement. Such quasi-integration, however, could also give the firm more opportunities for making selfserving decisions, such as intermittent procurement of parts that are not quite up to the quality standard originally envisioned. It can be expected that the incentive to make such self-serving decisions will be reduced when the firm bears more residual claimancy in the JV because the net benefit to the firm from such decisions would become lower. Thus, the optimal compensation structure could be altered by a change in the control structure due to an arrangement for quasiintegration. This reflects the old management principle that there should be a congruence between responsibility and authority (Roethlisberger and Dickson, 1939), which has recently been more rigorously demonstrated in agency models (Holmstrom, 1989).

To wit, the two dimensions of the exchange structure are not only distinct but also interrelated. Given that trading in strategic resources is often subject to both measurement and coordination difficulties, there must be a balanced choice of remedies for these two genres of transaction cost problems in designing the exchange structure.

\section{CONCLUSION}

The paper argues that a broader definition of trading is needed to conduct a full analysis of the exchanges involving imperfectly imitable and imperfectly mobile firm resources. The definition should include not only acquisition of a firm or part of it that possesses the resources in question but also trade in their service or knowledge base. Under this broader concept, the paper spells out a set of conditions for such strategic resources to be gainfully traded across firms. It then moves on to investigate what types of trading difficulties are likely to arise from a 
Chi, Tailan. (1994) Trading in Strategic Resources: Necessary Conditions, Transaction Cost Problems, and Choice of Exchange Structure. Strategic Management Journal, 15 (4), 271-290. Publisher’s official version:

<http://dx.doi.org/10.1002/smj.4250150403>. Open Access version: http://kuscholarworks.ku.edu/dspace/.

resource's imperfect imitability and imperfect mobility. After exploring the conceptual relationships between some prominent imitation barriers and various exchange difficulties, the paper identifies four primary transaction cost problems in the trading of strategic resources: adverse selection, moral hazard, cheating and holdup. Adverse selection and moral hazard result from difficulties in measuring the capabilities and efforts of an exchange partner and cause friction to the value creation process in the trading of strategic resources. Cheating and holdup result from resource interdependency created through the exchange and can cause failures in the coordination between the exchange parties that is necessary for the realization of the maximum possible rent from their resources.

The paper proceeds to investigate how these transaction cost problems might be remedied through a proper design of the exchange structure between the transacting parties. A twodimensional view of the exchange structure is proposed in the paper. One dimension concerns how the variation in the outcome of the exchange is born between the two parties. It is often referred to in the literature as the apportionment of residual claimancy (Barzel, 1989). A proper structural design along this dimension can minimize the friction in the value creation process brought about by adverse selection and moral hazard. The other dimension concerns how the effective control over the resources that the two parties might contribute to the venture is distributed between them. It is termed in the paper as the assignment of residual control, which is similar to what Grossman and Hart (1986) refer to as the residual rights of control. A proper structural design along this dimension can minimize the value dissipation due to cheating and holdup.

In the final part of the paper, it is shown that the features of different transaction modes can be rigorously defined along these two structural dimensions to facilitate the analysis of their respective capabilities in handling the various transaction cost problems. The analysis reveals that a collaborative venture has a wide range of structural flexibility in dealing with multiple transaction cost problems affecting the resources from both of the transacting parties and thus tends to be a more robust mode of transaction than outright acquisition. This view is consistent 
Chi, Tailan. (1994) Trading in Strategic Resources: Necessary Conditions, Transaction Cost Problems, and Choice of Exchange Structure. Strategic Management Journal, 15 (4), 271-290. Publisher’s official version:

<http://dx.doi.org/10.1002/smj.4250150403>. Open Access version: http://kuscholarworks.ku.edu/dspace/.

with the recently documented observations that the use of joint ventures (JVs) and other forms of collaborative arrangements between firms are much more common than suggested by conventional wisdom (Harrigan, 1988; Hergert and Morris, 1988). 
Chi, Tailan. (1994) Trading in Strategic Resources: Necessary Conditions, Transaction Cost Problems, and Choice of Exchange Structure. Strategic Management Journal, 15 (4), 271-290. Publisher’s official version:

<http://dx.doi.org/10.1002/smj.4250150403>. Open Access version: http://kuscholarworks.ku.edu/dspace/.

\section{APPENDIX: REPUTATION AS A REMEDY FOR MEASUREMENT DIFFICULTIES}

The establishment of reputation is sometimes touted as the most satisfactory remedy for the problems of adverse selection and moral hazard (Nayyar, 1990). In fact, if there exists some agency that has a superior measurement capability and a good reputation for its capability and honesty, the certification of such an agency can to some extent substitute for one's own reputation. But we will examine only the effect of one's own reputation here because certification does not seem to bear much relevance to the trading of strategic resources.

If a firm is known to have a particular set of capabilities (e.g., in biochemical research), any party that wishes to acquire those capabilities from the firm will undoubtedly experience less of an adverse selection problem. (Although the problem can not be completely eliminated because there is always some uncertainty as to whether the expertise is worth the price the firm charges.) In order to overcome the problem of moral hazard, however, the firm must also have a reputation for diligence in serving its exchange partners. Evidently, such a reputation is worth building only if the firm expects to sell its capabilities to a considerable number of acquirers later on. Yet, as more parties obtain access to the same set of capabilities, the economic value of the capabilities will depreciate unless the firm can effectively keep the acquirers from competing with one another. Frequently, a firm's capabilities are only applicable in a single industry or in a few related industries (perhaps with the exception of those specializing in such general skills as marketing research or organization development). Given this constraint, many firms will be unable to sell their capabilities to a diverse range of noncompeting entities and thus will have neither the opportunity nor the incentive to build such a reputation. In many instances of trading in strategic resources, therefore, reputation can not serve as a feasible remedy. 
Chi, Tailan. (1994) Trading in Strategic Resources: Necessary Conditions, Transaction Cost Problems, and Choice of Exchange Structure. Strategic Management Journal, 15 (4), 271-290. Publisher's official version:

<http://dx.doi.org/10.1002/smj.4250150403>. Open Access version: http://kuscholarworks.ku.edu/dspace/.

\section{NOTES}

${ }^{1}$ Rents are earnings in excess of break-even. See Peteraf (1993) for a discussion of different types of rents.

${ }^{2}$ This section, particularly the conditions specified in the last subsection, benefited greatly from detailed suggestions offered by an anonymous referee.

${ }^{3}$ The author is indebted to an anonymous referee for suggesting many ways to improve the readability of this paper, including the use of such concrete examples throughout the paper.

${ }^{4}$ Whether such an arrangement would be optimal, however, will be the topic of discussion in later sections.

${ }^{5} \mathrm{~A}$ resource can be shared in two or more independent uses under either of two conditions. First, if the resource has the property of a public good such as information, it can be shared in two or more independent uses. Such a resource can often be shared at a low incremental cost while the initial gathering of the information is much more costly than sharing. Second, if the resource can be divided into two or more portions without losing its features, it can again be used simultaneously for two or more independent purposes. If the creation of such a resource involves a significant start-up cost or its maintenance is subject to significant economies of scale, the incremental cost of sharing can also be much less than the cost of acquisition. See Williamson (1975: 42-43).

${ }^{6}$ The joint use, as suggested in the preceding subsection, does not have to preclude either set of resources from being used simultaneously or sequentially with other resources that also exhibit complementarity with them.

${ }^{7}$ The problem of moral hazard is not limited to managerial situations and can occur in any situation involving the exercise of discretion, such as due care in driving a car as required by an insurance contract.

${ }^{8}$ The acquirer could, of course, let the shares of the acquired firm still float in the stock market, as GM did with respect to the shares of EDS. But since the acquirer holds the main control rights, the managers of the acquired firm can no longer make independent decisions and the share price of the acquired firm is no longer a pure piece of its economic value (Holmstrom, 1989). This problem may be reduced (but not eliminated) if the managers of the acquired firm still hold a substantial portion of the firm's equity stock, as will be discussed later.

${ }^{9}$ Generally, firm specific skills reflect partly training by the employer and partly effort by the employee in learning. In order to induce the employee to exert the effort, the employer will need to promise a higher future pay that compensates the employee for his or her effort. The part of the pay that the employee receives in excess of the pay he or she would get from a second-highest valuing employer constitutes quasi-rents.

${ }^{10}$ The author is indebted to an anonymous referee for pointing out the blurring of this distinction under certain circumstances.

${ }^{11}$ This term is borrowed from Alchian and Woodward (1988) who use it to refer to the threat of breaking a prior commitment in a business relationship. But they seem to have ignored the issue of whether a contractual obligation is clearly specified ex ante or not and fail to distinguish cheating from what this paper defines as holdup.

${ }^{12}$ See Cooper and Ross $(1985,1988)$ for discussions on the use of warranties and deductions to mitigate measurement difficulties. An inherent dilemma in using such an arrangement for the trading of strategic resources stems from the condition that both of the exchange parties tend to have substantial influences on output quality and production efficiency that are reflected in a variety of imperfect indicators. In order to clarify the supplier's responsibility, its payment should be contingent upon many variables. Yet, the more contingencies are specified the more opportunities will the acquirer get to avoid or delay the payment via manipulation of those variables. So the efficiency of such a remedy depends on the extent to which there exist variables that are highly correlated with one party's contribution and can not be manipulated by the other party.

${ }^{13}$ The word profit here refers to accounting profit rather than economic profit since the costs of the difficult-tomeasure inputs can not be accurately accounted for.

${ }^{14}$ For the problem of shirking, behavioral control would be an effective remedy if the behavior in question is easy to measure and monitor. But our discussion of moral hazard in the paper is based on the presumption that behavioral monitoring is highly inaccurate and costly. So the use of residual claimancy amounts to the substitution of price constraints for deficient behavioral constraints in the terminology of Hennart (1993). Control over a contracting party's behavior is effective in curbing shirking only when the problem of moral hazard is minor.

${ }^{15}$ Given that strategic resources are difficult to replicate, this is probably an uncommon situation in reality.

${ }^{16}$ Ideally, the transacting parties would like to have the control rights to their complementary resources assigned through iron-clad, nonreversible contracts. But in the presence of transaction cost problems, they may have to utilize 
Chi, Tailan. (1994) Trading in Strategic Resources: Necessary Conditions, Transaction Cost Problems, and Choice of Exchange Structure. Strategic Management Journal, 15 (4), 271-290. Publisher’s official version:

<http://dx.doi.org/10.1002/smj.4250150403>. Open Access version: http://kuscholarworks.ku.edu/dspace/.

the often less perfect mechanism of residual control represented by property ownership and sometimes direct or even exclusive access.

${ }^{17}$ The temptation for cheating might also be reduced if the potential culprit is given some residual claimancy in the outcome. The most efficient solution to any severe hazards of cheating, however, is likely to entail the mechanism of residual control based on the preceding analysis. First, feasible price constraints are deficient and provide perverse incentives, particularly, when the subject of transaction has features of a public good (Hennart, 1993). Second, feasible contractual constraints on the behavior of the potential culprit suffer from deficient enforcement mechanisms due to imperfections in the legal system (Hennart, 1988; Teece, 1986). Finally, the decision to cheat typically involves a dichotomous choice in which a discrete gain is weighed against a discrete cost. So the effect of using partial residual claimancy is likely to be limited. In a technology transfer arrangement, for example, the licensor's ability to retaliate against cheating is usually a much more effective remedy than giving the licensee a higher share of the revenue from the use of the technology.

${ }^{18}$ As will discussed later, the moral hazard problem might be lessened by leaving part of the acquired firm's shares float in the stock market and giving the original management a stake in the firm's stock. But such an arrangement is closer to what we will define as a collaborative venture than an outright acquisition discussed here.

${ }^{19}$ The word some in the definition might be more appropriately substituted by nontrivial. Since trading in strategic resources is always subject to some transaction costs, pure arm's length deals hardly exist in such exchanges. So in reality we can only talk about whether an exchange relationship is close to an arm's length deal or a CV. In other words, the difference between an arm's length deal and a CV is in degree rather in kind. 


\section{REFERENCES}

Abreu, D., D. Pearce and E. Stacchetti, "Toward a theory of discounted repeated games with imperfect monitoring," Econometrica, 58, 1990, pp. 251-269.

Akerloff, G., "The market for lemons: Qualitative uncertainty and the market mechanism," Quarterly Journal of Economics, 84, 1970, pp. 488-500.

Alchian, A. A. and S. Woodward, "The firm is dead; long live the firm", Journal of Economic Literature, 116, 1988, pp. 65-79.

Arrow, K. J., "Economic welfare and the allocation of resources for invention," in National Bureau of Economic Research (ed.), The Rate and Direction of Inventive Activity, Princeton University Press, Princeton, NJ, 1962, pp. 609-625.

Barney, J. B., "Information cost and the governance of economic transactions," in R. D. Nacamalli and A. Rugiadini (eds.), Organization and Markets, Societa Editrice it Milano, Milan, Italy, 1985, pp. 347-372.

Barney, J. B., "Strategic factor markets: Expectations, luck, and business strategy," Management Science, 32, 1986a, pp. 1231-1241.

Barney, J. B., "Organization culture: Can it be a source of sustained competitive advantage," Academy of Management Review, 11, 1986b, pp. 656-665.

Barney, J. B., "Firm resources and sustainable competitive advantage," Journal of Management , 17, 1991, pp. 99-120.

Barzel, Y., "The choice of maximizing contracts in the face of exchange costs," Unpublished manuscript, University of Washington, 1987.

Barzel, Y., Economic Analysis of Property Rights, Cambridge University Press, Cambridge, U.K., 1989.

Casson, M. C., The Firm and the Market, MIT Press, Cambridge, MA 1987.

Caves, R. E., Multinational Enterprise and Economic Analysis, Cambridge University Press, Cambridge, U.K., 1982.

Cheung, S. N. S., "Transaction costs, risk aversion, and the choice of contractual arrangements," Journal of Law and Economics, 12, 1969, pp. 23-43.

Chi, T., "Transaction costs and structure of collaborative ventures," paper presented at the Western Economic Association, Seattle, Washington, 1991.

Contractor, F. J., International Technology Licensing: Compensation Costs and Negotiation, D. C. Heath \& Co., Lexington, MA, 1981.

Contractor, F. J. and P. Lorange, "Why should firms cooperate? The strategy and economic basis for cooperate ventures", in F. J. Contractor and P. Lorange (eds.), Cooperative Strategies in International Business, Lexington Books, Lexington, MA, 1987, pp. 3-28.

Coase, R., "The problem of social cost," Journal of Law and Economics, 3, 1960, pp. 1-44. 
Cooper, R. and T. Ross, "Product warranties and double moral hazard," Rand Journal of Economics, 16, 1985, pp. 103-113.

Cooper, R. and T. Ross, "An intertemporal model of warranties," Canadian Journal of Economics, 21, 1988, pp. 72-86.

Dierickx, I. and K. Cool, "Asset stock accumulation and sustainability of competitive advantage," Management Science, 35, 1989, pp. 1504-1513.

Eswaran, M. and A. Kotwal, "A theory of contractual structure in agriculture," American Economic Review, 75, 1985, pp. 352-367.

Grossman, S. J. and O. D. Hart, "The costs and benefits of ownership: A theory of vertical and lateral integration," Journal of Political Economy, 94, 1986, pp. 691-719.

Hallagan, W., "Self-selection by contractual choice and the theory of sharecropping," Bell Journal of Economics, 9, 1978, pp. 344-354.

Hamel, G., Y. Doz and C. K. Prahalad, "Collaborate with your competitors-and win," Harvard Business Review, January-February, 1989, pp. 133-139.

Harrigan, K. R., "Joint ventures and competitive strategy," Strategic Management Journal, 9, 1988, pp. 141-158.

Hennart, J.-F., "A transaction cost theory of equity joint ventures", Strategic Management Journal, 9, 1988, pp. 361-374.

Hennart, J.-F., "Can 'new forms of investment' substitute for the old forms? A transactions cost perspective," Journal of International Business Studies, 20, 1989, pp. 211-234.

Hennart, J.-F., "The transaction costs theory of joint ventures: An empirical study of Japanese subsidiaries in the United States", Management Science, 37, 1991, pp. 483-497.

Hennart, J.-F., "Explaining the swollen middle: Why most transactions are a mix of 'market' and 'hierarchy'", Organization Science, 4, 1993, pp. 529-547.

Hergert, M. and D. Morris, "Trends in international cooperative arrangements," in F. J. Contractor and P. Lorange (eds.), Cooperative Strategies in International Business, Lexington Books, Lexington, MA, 1987, pp. 99-109.

Hill, C. W. L., "Cooperation, opportunism, and the invisible hand: Implications for transaction cost theory," Academy of Management Review, 15, 1990, pp. 500-513.

Hill, C. W. L., "A paradigm for strategic management: The resource based view of the firm," working paper, University of Washington, Seattle, Washington, 1991.

Hitt, M. A. and R. D. Ireland, "Corporative distinctive competence, strategy, industry and performance," Strategic Management Journal, 6, 1985, pp. 273-293.

Hitt, M. A. and R. D. Ireland, "Relationships among corporate distinctive competencies, diversification strategy, corporate structure and performance," Journal of Management Studies, 23, 1986, pp. 401-416. 
Holmstrom, B., "Moral hazard and observability," Bell Journal of Economics, 10, 1979, pp. 7491.

Holmstrom, B., "Moral hazard in teams," Bell Journal of Economics, 13, 1982, pp. 324-340.

Holmstrom, B., "Agency cost and innovation," Journal of Economic Behavior and Organization, 12, 1989, pp. 305-327.

Killing, J. P., Strategies for Joint Venture Success, Praeger, New York, 1983.

Klein, O., R. Crawford and A. Alchian, "Vertical integration, appropriable rents, and the competitive contracting process," Journal of Law and Economics, 21, 1978, pp. 297-326.

Kogut, B., "Joint ventures: Theoretical and empirical perspectives," Strategic Management J., 9, 1988, pp. 319-332.

Kreps, D. M., A Course in Microeconomic Theory, Princeton University Press, Princeton, NJ, 1990.

Lazear, E. P., "Why is there mandatory retirement," Journal of Political Economy, 87, 1979, pp. 1261-64.

Lippman, S. and R. P. Rumelt, "Uncertain imitability: An analysis of interfirm differences in efficiency under competition," Bell Journal of Economics, 13, 1982, pp. 418-438.

McGee, S. P., "Information and the multinational corporation: An appropriability theory of direct investment," in J. N. Bhagwati (ed.), The New International Economic Order, MIT Press, Cambridge, MA, 1977, pp. 317-340.

Milgrom, P. and J. Roberts, "Bargaining costs, influence costs and the organization of economic activity," In J. E. Alt and K. A. Shepsle (eds.), Perspectives on Positive Political Economy, Cambridge University Press, Cambridge, U.K., 1990, pp. 57-89.

Monteverde, K. and D. J. Teece, "Appropriable rents and quasi-vertical integration," Journal of Law and Economics, 25, 1982, pp. 321-328.

Nayyar, P. R., "Information asymmetries: A source of competitive advantage for diversified service firms," Strategic Management Journal, 11, 1990, pp. 513-519.

Nelson, R. and S. Winter, An Evolutionary Theory of Economic Change, Harvard University Press, Cambridge, MA, 1982.

Penrose, E. T., The Theory of the Growth of the Firm. Blackwell, Oxford, 1959.

Peteraf, M., "The cornerstones of competitive Advantage: A resource-based view," Strategic Management Journal, 14, 1993, pp. 179-191.

Pisano, R. P., "Using equity participation to support exchange: Evidence from the biotechnology industry," Journal of Law, Economics and Organization, 5, 1989, pp. 109-126.

Polanyi, M., The Tacit Dimension, Anchor, Garden City, NY, 1967.

Porter, M. E., Competitive Strategy, Free Press, New York, 1980. 
Reed, R. and R. DeFillippi, "Causal ambiguity, barriers to imitation, and sustainable competitive advantage," Academy of Management Review, 15, 1990, pp. 88-102.

Roethlisberger, F. and W. J. Dickson, Management and the Worker, Harvard University Press, Cambridge, MA, 1939.

Rubinstein, A., "Perfect equilibrium in a bargaining model," Econometrica, 50, 1982, pp. 97110.

Rugman, A. M., Inside the Multinationals: The Economics of Internal Markets, Croom Helm, London, 1981.

Rumelt, R. P., Strategy, Structure and Economic Performance, Harvard University Press, Cambridge, MA, 1974.

Rumelt, R. P., "Towards a strategic theory of the firm," in R. Lamb (ed.), Competitive Strategic Management, Prentice-Hall, Englewood, NJ, 1984, pp. 556-570.

Shan, W., Technical Change and Strategic Cooperation: Evidence from Commercialization of Biotechnology, University Microfilms, Ann Arbor, MI, 1987.

Shan, W., "An empirical analysis of organizational strategies by entrepreneurial high-technology firms," Strategic Management Journal, 11, 1990, pp. 129-139.

Snow, C. C. and L. G. Hrebiniak, "Strategy, distinctive competence and organizational performance," Administrative Science Quarterly, 25, 1980, pp. 317-336.

Stuckey, J., Vertical Integration and Joint Ventures in the Aluminum Industry, Harvard University Press, Cambridge, MA, 1983.

Sutton, J., "Noncooperative bargaining theory: An introduction," Review of Economic Studies, 53, 1986, pp. 709-274.

Teece, D. J., "Towards an economic theory of the multiproduct firm," Journal of Economic Behavior and Organization, 3, 1982, pp. 39-63.

Teece, D. J., "Profiting from technological innovation: Implications for integration, collaboration, licensing and public policy," Research Policy, 15, 1986, pp. 285-305.

Telser, L. G., "A theory of self-enforcing agreements," Journal of Business, 53, 1980, pp. 27-44.

Wernerfelt, B., "A resource-based view of the firm," Strategic Management Journal, 5, 1984, pp. 171-180.

Wernerfelt, B., "From critical resources to corporate strategy," Journal of General Management, 14, 1989, pp. 4-12.

Williamson, O. E., Markets and Hierarchies: Analysis and Antitrust Implications, Free Press, New York, 1975.

Williamson, O. E., "Credible commitments: Using hostages to support exchange," American Economic Review, 73, 1983, pp. 519-540.

Williamson, O. E., The Economic Institutions of Capitalism, Free Press, New York, 1985. 